\title{
PERFORMANCE OF SPRAY NOZZLES IN LAND APPLICATIONS WITH HIGH SPEED
}

\section{SAMIR E. ZAIDAN ${ }^{1}$, CASIMIRO D. GADANHA JR. ${ }^{2}$, MARCO A. GANDOLFO ${ }^{3}$, CRISTIANO O. PONTELLI ${ }^{4}$, WALTER W. MOSQUINI ${ }^{5}$}

\begin{abstract}
The aim of this study was to evaluate different spray nozzles for land applications in high speed on the coverage and deposit in soybean plants pulverization. It was evaluated the AXI 11004 plane jet nozzles operated at speed of $4.17 \mathrm{~m} . \mathrm{s}^{-1}$ (control), the grey APE and the AXI 11008 plane jets, and the TD HiSpeed 11006 and AXI TWIN 12006 twin jets, at speed of $9.72 \mathrm{~m} . \mathrm{s}^{-1}$. The application volume was fixed in $120 \mathrm{~L} \mathrm{ha}^{-1}$. The application efficiency was evaluated by two different methods: analysis of the coverage area using fluorescent pigment and UV light and analysis of deposits through the recovery and quantification of FD\&C $\mathrm{N}^{\circ} 1$ brilliant blue marker by spectrophotometry. Both analyses were done in samples collected from top, middle and bottom parts of the plants. The spray nozzles showed differences in coverage and deposit pattern, so in the top part, the coverage was increased with smaller drops and the deposits were increased with medium drops. In the other parts of the plants, there were no statistical differences between the treatments for both coverage and deposits. The displacement speed did not influence the application efficiency for nozzles with the same drop pattern, and the obtained spray coverage and deposits at the medium and bottom parts of the plants were less than $50 \%$ of that found at the top of the soybean plants.
\end{abstract}

KEYWORDS: Spray nozzles, speed, soybean, pulverizer.

\section{DESEMPENHO DE PONTAS DE PULVERIZAÇÃO EM APLICAÇÕES TERRESTRES COM ALTA VELOCIDADE}

RESUMO: O objetivo do trabalho foi avaliar o efeito de diferentes pontas de pulverização para aplicações terrestres em alta velocidade sobre a cobertura e depósito da pulverização em plantas de soja. Foram avaliadas as pontas de jatos planos AXI 11004 à velocidade de 4,17 m.s ${ }^{-1}$ (testemunha), de jatos planos APE cinza e AXI 110 08, e de jatos planos duplos TD HiSpeed 110 06 e AXI TWIN 120 06, à velocidade de deslocamento de $9,72 \mathrm{~m} \cdot \mathrm{s}^{-1}$. O volume de aplicação foi fixado em 120 L.ha $^{-1}$. A eficiência de aplicação foi avaliada por dois métodos: análise visual do percentual de cobertura, utilizando marcador fluorescente e com luz ultravioleta, e análise de depósito através da recuperação e da quantificação do marcador Azul Brilhante FD\&C $\mathrm{N}^{\circ} 1$ por espectrofotometria. Ambas as análises foram realizadas em amostras retiradas das partes superior, média e inferior das plantas. As pontas de pulverização mostraram padrões de cobertura e depósito diferenciados, de modo que, na parte superior, a cobertura foi favorecida por gotas mais finas e o depósito melhorado pelo uso de gotas médias. Nas demais partes da planta, não houve diferença estatística entre os tratamentos para cobertura e depósito. A velocidade de deslocamento não interferiu na eficiência da aplicação para pontas com o mesmo padrão de gota, sendo os níveis dos depósitos e da cobertura nos terços inferior e médio inferiores a 50\% dos obtidos na parte superior das plantas.

PALAVRAS-CHAVE: Bicos, velocidade, soja, pulverizador.

\footnotetext{
${ }^{1}$ Engenheiro Agrônomo, Msc, Departamento de Engenharia de Biossistemas, ESALQ/Piracicaba-SP, se_zaidan@yahoo.com.br

${ }^{2}$ Engenheiro Agrônomo, Prof. Doutor, Departamento de Engenharia de Biossistemas, ESALQ/Piracicaba-SP.

${ }^{3}$ Engo Agrônomo, Doutor, Professor Adjunto, Universidade Estadual do Norte do Paraná, Bandeirantes - PR, Brasil, gandolfo@uenp.edu.br.

${ }^{4}$ Engenheiro Mecânico, mestre, gerente de projetos, Máquinas Agrícolas Jacto S/A.

${ }^{5}$ Eng. Agr. Walter Wagner Mosquini - Especialista em Tecnologia de Aplicação - Máquinas Agrícolas Jacto S/A.

Recebido pelo Conselho Editorial em: 30-8-2011
}

Aprovado pelo Conselho Editorial em: 24-6-2012 


\section{INTRODUCTION}

Soybean is one of the main raw materials for ration production for animal feed and vegetable oil (NASCIMENTO et al., 2009).

The crop protection through the application of agrochemicals is currently considered one of the most critical phases in the production cycle of soybeans in Brazil, either by costs or by the complexity involved in this process, since the final result of the operation depends on the interaction of various factors, many of them of a limited control (GILES et al., 2008). A high efficiency application is that in which is obtained the control or the complete elimination of the phytopathogenic agents and weeds allowing at least the maintenance of the productivity potential of the agricultural crops.

The reduced efficiency of an application can bring loss to the producer, causing since a reapplication in the affected area until the complete loss of the productive potential of the crop, which characterizes the importance of application technology knowledge of agricultural pesticides.

The application technology of agrochemicals is defined as the correct placement of the active ingredient in contact with the target in the proper amount, evenly and with minimum environmental contamination (MATUO, 1990).

Among the main aspects related to technology application, the appropriate selection and use of spray nozzles are emphasized. The knowledge of the form of application becomes extremely important to ensure that the product reaches the target efficiently, thus minimizing losses. For this, it is necessary application uniformity and drop spectrum suitable for the target to be treated (BALAN et al., 2008).

Associated with the problem of application technology, there has been an increase in recent years in the areas of soybean production in Brazil. This increase of area and also of intensity of cultivation is causing consequently greater pressure on crop pests and diseases, especially the Asian Soybean Rust (CHRISTOVAM et al., 2010). Therefore, greater is the need for application of agricultural pesticides at closer time intervals (WOLF; DAGGUPATI, 2009).

This change has required greater operational capacity of the machines for pulverization of the land without detriment to the quality of implementation. This increased operating capacity can be obtained by increasing the length of the spray bars, reducing the time lost or, as often is occurring, increasing the forward speed of the equipment, especially in regions where the relief is presented with low slope.

The relation between increased displacement speed in terrestrial applications and application efficiency depends on several factors. Among them, it can be highlighted the attributes mainly related to the spray nozzles as the drop spectrum, constructive characteristics of spray nozzles and air induction system. The quality assessment in applications is generally performed by using markers that simulate the agrochemical. The attributes of deposit and coverage are the two most important components of the performance of an application and is of utmost importance to be quantified in order to evaluate the efficiency of pulverization in the field (YU et al., 2009).

The preview of drops deposited on the leaves using fluorescent markers allows identifying where the product is deposited, as well as showing their distribution and intensity of coverage, allowing a full qualitative analysis.

The aim of this research was to study the performance of different pulverization nozzles in the coverage and leaf deposit in terrestrial applications of agrochemicals with high displacement speeds of the applicator machine in soybean crops.

\section{MATERIAL AND METHODS}


The experiment was conducted at the Igreja Velha Farm in Tibagi city - state of Paraná (PR), Brazil, in soybean commercial farming, cultivar BRS 284 sown at a space of $0.45 \mathrm{~m} \times 0.08 \mathrm{~m}$ in January 2011. The area used presented flat topography and without the presence of terraces. The plants had an average height of $1.1 \mathrm{~m}$ and leaf area index (LAI) of 7.1. It was used for the applications spray bars self-propelled by the manufacturer Jacto Agricultural Machines S/A with pulverization bars of $32 \mathrm{~m}$ space between the nozzles of $0.5 \mathrm{~m}$ and adapted to apply at speed up to $9.72 \mathrm{~m} \mathrm{~s}^{-1}$. The spray solution consisted of a concentrate suspension containing LRM 100 yellow fluorescent marker at a concentration of $5 \mathrm{~g} . \mathrm{L}^{-1}$ and $\mathrm{FD} \& \mathrm{C} \mathrm{N}^{\circ} 1$ brilliant blue marker at a concentration of $5 \mathrm{~g} . \mathrm{L}^{-1}$. The design was in randomized blocks with 5 treatments in 5 replicates. The description of the treatments is shown in Table 1. The application volume was fixed in all treatments in $120 \mathrm{~L} \cdot \mathrm{ha}^{-1}$ and the application high was kept constant at $0.5 \mathrm{~m}$ above the crop canopy.

TABLE 1. Description of the treatments and respective class of drop size (ASABE, 2009).

\begin{tabular}{lllllll}
\hline Treatment & $\begin{array}{l}\text { Model of spray } \\
\text { nozzle }\end{array}$ & $\begin{array}{l}\text { Type } \\
\text { of } \\
\text { nozzle }\end{array}$ & $\begin{array}{l}\text { Pulverization } \\
\text { angle }\end{array}$ & $\begin{array}{l}\text { Displacement } \\
\text { speed }\left(\mathrm{m}^{-1} \mathrm{~s}^{-1}\right)\end{array}$ & $\begin{array}{l}\text { Work } \\
\text { pressure } \\
(\mathrm{kPa})\end{array}$ & $\begin{array}{l}\text { Drop class } \\
\text { (ASABE) }\end{array}$ \\
\hline T1 & AXI 110 04 & Fan & 110 & 4.17 & 293 & Mean \\
T2 & APE grey & Fan & 110 & 9.72 & 409 & Mean \\
T3 & AXI 110 08 & Fan & 110 & 9.72 & 443 & Thick \\
T4 & HiSpeed 110 06 & Fan & 110 & 9.72 & 730 & Very Thick \\
T5 & AXI Twin 120 06 Fan & 120 & 9.72 & 798 & Thin \\
\hline
\end{tabular}

The weather conditions at the time the applications were monitored with digital term hygrometer Minipa MDA-11 model (Table 2).

TABLE 2. Climatic conditions of air temperature, relative air humidity and wind speed during spray applications.

\begin{tabular}{lllllll}
\hline Treatment & $\begin{array}{l}\text { Air temperature } \\
\left({ }^{\circ} \mathrm{C}\right)\end{array}$ & $\begin{array}{l}\text { Air } \\
(\%)\end{array}$ & Relative & humidity & $\begin{array}{l}\text { Wind speed } \\
\left(\mathrm{m} . s^{-1}\right)\end{array}$ \\
\cline { 2 - 7 } & Minimum & Maximum & Minimum & Maximum & Minimum & Maximum \\
\hline T1 & 29.9 & 34.6 & 37 & 66 & 1.2 & 3.0 \\
T2 & 29.9 & 33.4 & 39 & 64 & 0.7 & 3.4 \\
T3 & 29.8 & 34.6 & 37 & 66 & 1.3 & 3.1 \\
T4 & 29.1 & 36.4 & 48 & 64 & 1.0 & 4.6 \\
T5 & 29.5 & 32.5 & 45 & 62 & 0.8 & 2.5 \\
\hline
\end{tabular}

After the applications it was collected 90 soybean leaflets per experimental portion for quantification of coverage (\%), with 30 samples from each third of the plants: top, middle and bottom. For analysis of deposit, 75 samples were collected per portion, with 25 samples from each third of the plants: top, middle and bottom. After collection, the samples were placed in an environment without light and conducted to the lab. For coverage analysis it was constructed a scale of 0 to $100 \%$ under ultraviolet light, and based on this scale, the other samples were classified in the experiment. In the analysis of deposit, the samples collected in the field were washed with a known volume of distilled water $\left(80 \mathrm{~cm}^{3}\right)$ and then the wash solution was referred to be quantified by spectrophotometry. The leaf area was determined for each sample through predetermined correlation algorithm between the real surface and the product of the maximum width and maximum length of the leaflets. Losses have been estimated from the difference between the values of the deposit measured in the plant and the theoretical deposit expected to this volume of application and marker concentration in the suspension in each treatment. The statistical analysis consisted of applying $\mathrm{F}$ hypothesis test with a level of 5\% probability of error associated with a mean multiple comparison test by Tukey also with $5 \%$ probability of error. 


\section{RESULTS AND DISCUSSION}

The analysis of variance revealed significant differences in leaf coverage (\%) among the studied treatments due to the evaluated plant stratum (Figure 1).

At the top of the plants, the use of the AXI TWIN 12006 (T5) nozzle provided the greatest coverage value which was statistically higher than the coverage provided by the AXI 11008 (T3) nozzle. This difference is due to the AXI TWIN 12006 nozzle produce a drop spectrum thinner than the other, allowing greater coverage $(\%)$ of the target, justified by the effects of the dynamics of drops in relation to the high speed of the spray, where thinner drops are more susceptible to energy loss due to the relative speed between the machine and the pulverization target. In the other strata, there was no statistical difference between treatments. The treatments also showed differences in level of deposit $\left(\mu \mathrm{g} . \mathrm{cm}^{-2}\right)$ as it can be seen in Figure 2.

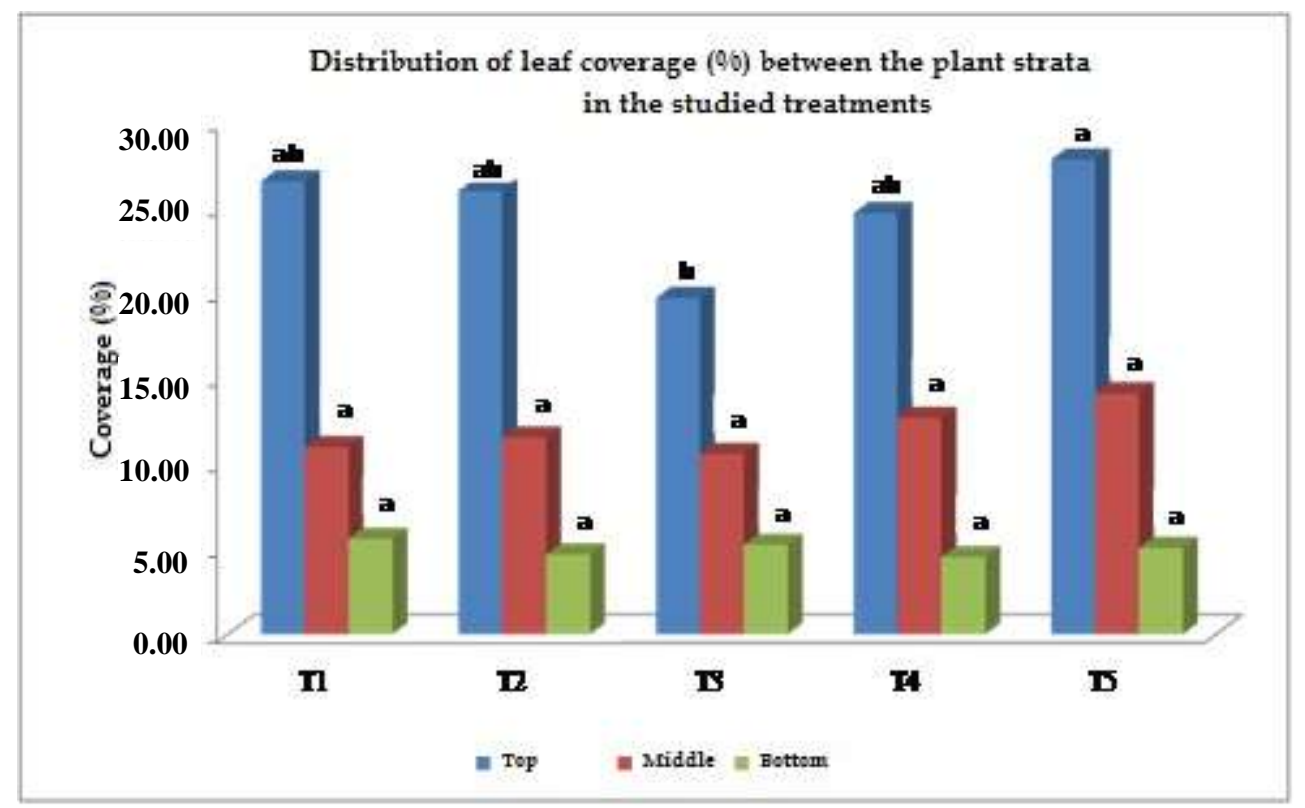

FIGURE 1. Leaf coverage (\%) in the respective treatments and strata of soybean plants. Same letter means that treatments do not statistically differ in each stratum of the plant.

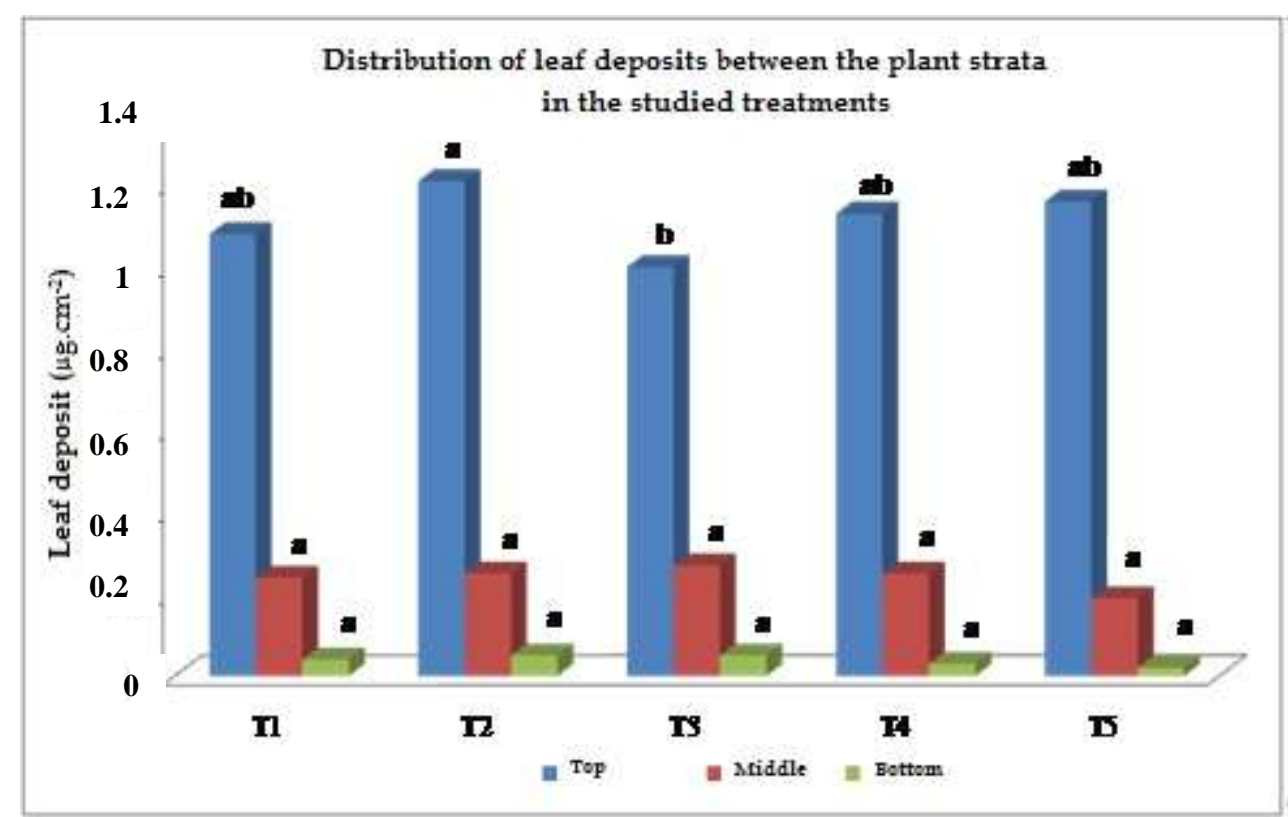

FIGURE 2. Leaf deposit $\left(\mu \mathrm{g} . \mathrm{cm}^{-2}\right)$ in each treatment and stratum of soybean plant. Same letter means that treatments do not statistically differ in each stratum of the plant. 
In the deposit analysis, the grey APE nozzle provided deposits greater than the AXI 11008 nozzle probably due to the medium drop spectrum of the first, according to results obtained by Oliveira and Antuniassi (2011) who proved the most efficiency of mean drops to achieve the control of Asian Soybean Rust.

In the other strata, there was no difference between treatments. Moreover, there are extremely low values of coverage, showing that the penetration of drops to all studied treatments in soybean crops is strongly influenced by conditions of high LAI as reported by Christovam et al. (2010).

The relation between the two measured efficiency parameters, coverage and foliar deposit shows a different behavior between the strata. Thus, while the values of leaf deposit were higher than the coverage in the top strata, the relation was reversed at the bottom (Figure 3). It can presume that occurred the effect of the vertical stratification of the drops along the crop canopy with larger drops concentrating on the top stratum and finer drops focusing on the bottom strata because of the great power of penetration in the leaf mass as reported by Cunha et al. (2011) and Nascimento et al. (2009).

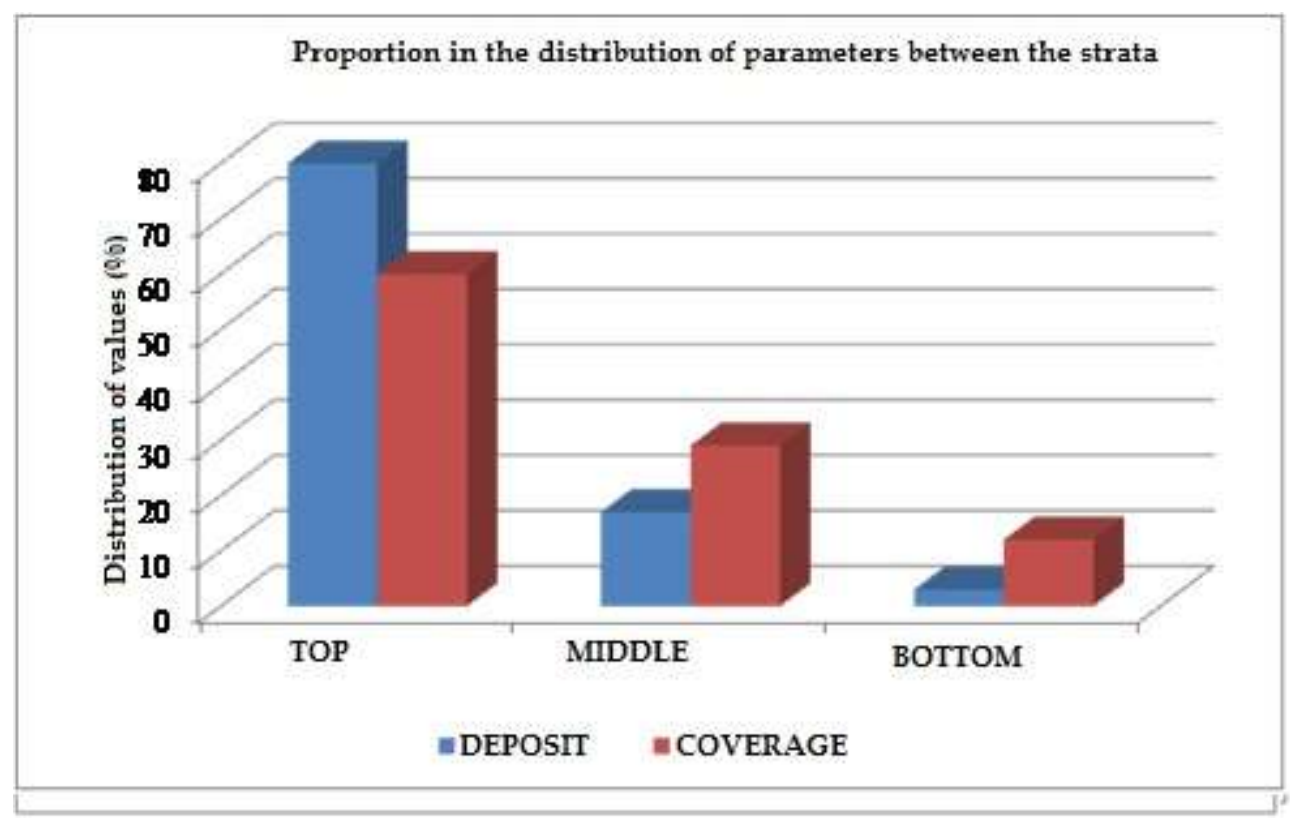

FIGURE 3. Relative percentage values of coverage and leaf deposit in each stratum of the plant.

Based on the mean and theoretical values of deposit and the leaf area index, an estimate was made of losses (\%) in each treatment (Table 3).

TABLE 3. Loss estimation (\%) in each treatment.

\begin{tabular}{llll}
\hline TREATMENTS & $\begin{array}{l}\text { Total mean deposit } \\
\left(\mu \mathrm{g} . \mathrm{cm}^{-2}\right)\end{array}$ & $\begin{array}{l}\text { Plant mean } \\
\left(\mu \mathrm{g} . \mathrm{cm}^{-2}\right)\end{array}$ & deposit \\
\hline T1 & 0.840 & 0.450 & 32.8 \\
T2 & 0.840 & 0.500 & 28.6 \\
T3 & 0.840 & 0.440 & 33.6 \\
T4 & 0.840 & 0.470 & 31.1 \\
T5 & 0.840 & 0.460 & 31.9 \\
\hline
\end{tabular}

It is observed that the grey APE (T2) nozzle showed a lower index of losses. This effect is due to better utilization of medium size and more uniform drops by the plant. The AXI 11008 (T3) nozzle, repeating the performance obtained to coverage and leaf deposit, had the highest index of losses, probably due to the high variability of the drops produced by favoring possible losses to the environment. 
The observed index of losses was greater than that observed by Gil et al. (2008) which reported losses between 10 and $20 \%$ and were consistent with the results found by Chaim et al. (2000).

\section{CONCLUSIONS}

The high displacement speed did not influence the efficiency of application in the lower strata in which are deposited less than $50 \%$ of the amount of active ingredient deposited on the top stratum of the soybean plant.

There was no influence of the type of spray nozzle used in the application efficiency, in the percentage of coverage or in leaf deposit in soybean leaflets.

\section{ACKNOWLEDGMENTS}

The authors thank the Jacto Agricultural Machinery S/A for providing the equipment and the State University of Northern Paraná by the support staff in the conduction of the field work.

\section{REFERENCES}

ASABE. American Society of Agricultural and Biological Engineering. ASABE S572: Spray Nozzle Classification by Droplet Spectra. St Joseph, 2009. 3p.

BALAN, M. G.; ABI SAAB, O. J. G.; SILVA, C. G.; RIO, A. Deposição de calda pulverizada por três pontas de pulverização sob diferentes condições meteorológicas, Ciências Agrárias, Londrina, v.29, n.2, p.293-298, 2008.

CUNHA, J.P.A.R., FARNECE, A.C., OLIVET, J.J., VILLALBA, J. Deposição de calda pulverizada na cultura da soja promovida pela aplicação aérea e terrestre, Engenharia Agrícola, Jaboticabal, v. 31, n. 2, p. $343-351,2011$

CHAIM, A.; VALARINI, P. J.; PIO, L.C. Avaliação de perdas na pulverização de agroquímicos na cultura do feijão. Revista de Ecotoxicologia e Meio Ambiente, Curitiba, v. 10, n.1, p. 13-22, 2000.

CHRISTOVAM, R. S.; RAETANO, C. G.; AGUIAR JUNIOR, H. O.; AMARAL, M. H. F.; PRADO, E. P.;GIMENES, M. J.; KUNZ, V. L. Assistência de ar em barra de pulverização no controle da ferrugem asiática da soja. Bragantia, Campinas, v.69, n.1, p.231-238, 2010

GIL, Y. Influence of micrometeorological factors on pesticide loss to the air during vine spraying: Data analysis with statistical and fuzzy inference models. Biosystems Engineering, Amsterdam, v.100, n.2, p. $184-197,2008$

GILES, D. K.; AKESSON, N. B.; YATES, W. E. Pesticide application technology: research and development and growth of the industry. Transactions of the ASABE, St. Joseph, v.51, n.2, p. 397403, 2008.

MATUO, T. Técnicas de aplicação de defensivos agrícolas. Jaboticabal: FUNEP, 1990. 139p.

NASCIMENTO, J. M.; SOUZA, C. M. A.; GAVASSONI, W. L.; BACCHI, L. M. A.; FENGLER, G. W. Controle de ferrugem asiática da soja utilizando-se diferentes pontas de pulverização em Maracajú - MS. Revista Ciências Técnicas Agropecuárias, v.18, n.1, p. 17-22, 2009.

OLIVEIRA, M.A.P.; ANTUNIASSI, U.R. Eficácia do flutriafol e do flutriafol + tiofanato metílico aplicados com gotas finas ou médias no controle da ferrugem asiática da soja. Revista Energia na Agricultura, Botucatu, v.26, n.1, p. 94-112, 2011

WOLF, R. E., DAGGUPATI, N. P. Nozzle Type Effect on Soybean Canopy Penetration. Applied Engineering in Agriculture, St. Joseph, v.25, n.1, p.23-30, 2009. 
YU, Y.; ZHU, H.; FRANTZ, J.; REDING, M.E.; CHAN, K.C. Evaporation and coverage area of pesticide droplets on hairy and waxy leaves. Biosystems Engineering, Amsterdam, v.101, n.3, p. 1 $11,2009$. 